\title{
Ceftezole Sodium
}

National Cancer Institute

\section{Source}

National Cancer Institute. Ceftezole Sodium. NCI Thesaurus. Code C98231.

The sodium salt form of ceftezole, a semi-synthetic first-generation cephalosporin with antibacterial activity. 